\title{
Tumor-Suppressor Functions of the TP53 Pathway
}

\author{
Brandon J. Aubrey, ${ }^{1,2,3}$ Andreas Strasser, ${ }^{1,2}$ and Gemma L. Kelly ${ }^{1,2}$ \\ ${ }^{1}$ The Walter and Eliza Hall Institute of Medical Research, Parkville, Victoria 3052, Australia \\ ${ }^{2}$ Department of Medical Biology, University of Melbourne, Parkville, Victoria 3050, Australia \\ ${ }^{3}$ Department of Clinical Haematology and Bone Marrow Transplant Service, The Royal Melbourne \\ Hospital, Parkville, Victoria 3050, Australia \\ Correspondence: strasser@wehi.edu.au; gkelly@wehi.edu.au
}

The fundamental biological importance of the Tp53 gene family is highlighted by its evolutionary conservation for more than one billion years dating back to the earliest multicellular organisms. The TP53 protein provides essential functions in the cellular response to diverse stresses and safeguards maintenance of genomic integrity, and this is manifest in its critical role in tumor suppression. The importance of Tp53 in tumor prevention is exemplified in human cancer where it is the most frequently detected genetic alteration. This is confirmed in animal models, in which a defective Tp53 gene leads inexorably to cancer development, whereas reinstatement of TP53 function results in regression of established tumors that had been initiated by loss of TP53. Remarkably, despite extensive investigation, the specific mechanisms by which TP53 acts as a tumor suppressor are yet to be fully defined. We review the history and current standing of efforts to understand these mechanisms and how they complement each other in tumor suppression.

$T_{s}^{\text {he }}$ he TP53 protein is a critical tumor suppressor that plays a fundamental and multifaceted role in the development of cancer and cancer therapy. Despite more than 30 years of vigorous research and an expansive body of literature, the precise molecular mechanism underlying TP53's tumor-suppressor function has not been defined and remains the focus of active investigation. Understanding the tumorsuppressor function of the Tp53 gene will not only have profound importance to the understanding of cancer biology but will likely have an impact on cancer therapy and prevention through improved exploitation of wild-type
Tp53 functions as well as gained insight into specific vulnerabilities imposed on tumors by loss of TP53 function. The TP53 protein exerts effector functions that impact on virtually all of the hallmark features of cancer (Hanahan and Weinberg 2011); however, it is still not clear which of these functions is essential to its potent tumor-suppressor function and how these functions interact. Indeed, it is becoming increasingly apparent that multiple pathways are likely to collaborate in exerting this tumor-suppression function and that the TP53 protein has context-specific roles. Here we discuss the functioning of the TP53 protein as a tumor suppres-

Editors: Guillermina Lozano and Arnold J. Levine

Additional Perspectives on The p53 Protein available at www.perspectivesinmedicine.org

Copyright (C) 2016 Cold Spring Harbor Laboratory Press; all rights reserved; doi: 10.1101/cshperspect.a026062

Cite this article as Cold Spring Harb Perspect Med 2016;6:a026062 
B.J. Aubrey et al.

sor and review efforts to understand the underlying mechanisms.

\section{THE TUMOR-SUPPRESSOR TP53 PROTEIN}

The TP53 protein was first discovered in 1979 through its association with simian virus 40 (SV-40) large T antigen in virally transformed cancer cells (DeLeo et al. 1979; Lane and Crawford 1979; Linzer and Levine 1979). For the first decade following its discovery, the TP53 protein was considered to be encoded by a protooncogene because of its effect on increasing cell growth and survival when forcibly expressed in cell lines. It is now known that this initial research describing TP53 function was inadvertently performed on mutant $T p 53$ genes rather than the wild-type form (Levine and Oren 2009). The realization of its role as a tumor suppressor came from a number of important observations. In 1989, the Tp53 gene was identified as the target of the frequently re-occurring 17 p chromosomal deletion observed in human colorectal carcinoma (Baker et al. 1989) with $>50 \%$ of these tumors harboring missense mutations in the remaining Tp53 allele. The high frequency of $T p 53$ inactivation strongly suggested its tumor-suppressor function. Moreover, in the same year, it was shown that enforced expression of the wild-type TP53 protein could block oncogene-mediated transformation of primary rat embryonic fibroblasts in culture (Eliyahu et al. 1989; Finlay et al. 1989).

The role of the TP53 protein in tumor suppression has been experimentally proven and further examined using mouse models generated by gene targeting. Confirming the tumorsuppressor function of the Tp53 gene, Tp53 knockout $\left(T p 53^{-/-}\right)$mice and mice with lossof-function mutations in Tp53 develop spontaneous tumors with $100 \%$ incidence by 9 mo of age (Donehower et al. 1992; Jacks et al. 1994; Lang et al. 2004; Olive et al. 2004). Interestingly, the genetic background influences the tumor spectrum: $T p 53^{-/-}$mice on a C57BL/6 background mostly develop thymic lymphoma, whereas sarcomas, hemangiomas, B-cell lymphomas, and breast cancers can arise on 129SV, $\mathrm{BALB} / \mathrm{c}$, or mixed genetic backgrounds (Harvey et al. 1993a; Jacks et al. 1994; Nacht et al. 1996). The $T p 53^{-/-}$mice also have an increased susceptibility to carcinogen and $\gamma$-irradiationinduced tumor development (Harvey et al. 1993b; Kemp et al. 1994), consistent with the critical role of the TP53 protein in the cellular response to DNA damage. Inactivation of the TP53 pathway can also markedly accelerate oncogene-driven tumor development (Eischen et al. 1999; Schmitt et al. 1999; Michalak et al. 2009). In addition to preventing spontaneous tumor formation, the TP53 protein exerts a strong tumor-suppressive effect in established TP53-deficient tumors. Inducible restoration of the wild-type TP53 protein in established tumors that had been elicited by loss of TP53 function leads to tumor regression and prolonged survival of tumor-burdened mice (Martins et al. 2006; Ventura et al. 2007; Xue et al. 2007). Interestingly, functional TP53 restoration in such tumors in vivo shows dramatic context dependence, with induction of apoptosis in lymphomas but cellular senescence in sarcomas. This may relate to the type of transformed cells or the nature of the oncogenic lesions that drove their transformation (in addition to loss of TP53) (Junttila et al. 2010). Regardless, these studies affirmed the TP53 tumor-suppressor function in vivo.

The importance of the Tp53 gene as a tumor suppressor is highlighted in human cancer where it is the most commonly mutated gene, with mutations found in a broad variety of cancer types (Vogelstein et al. 2000; Petitjean et al. 2007). Furthermore, in cancers in which the Tp53 gene remains intact, TP53 function is often impaired, for example, by interference from viral proteins or up-regulation of negative regulators, such as the E3 ubiquitin ligase, MDM2 (called HDM2 in humans) (Vogelstein et al. 2000). Thus, most human cancers contain a genetic or epigenetic alteration that impairs the TP53 pathway.

The requirement for normal TP53 function in tumor suppression is evident in families with the $\mathrm{Li}$-Fraumeni syndrome, which are prone to spontaneous tumor formation ( $\mathrm{Li}$ and Fraumeni 1969) owing to the inheritance of a germline loss-of-function mutation in one Tp53 
allele (Malkin et al. 1990; Srivastava et al. 1990). $\mathrm{Li}-$ Fraumeni syndrome patients typically develop cancer before the age of $45 \mathrm{yr}$, which most often presents as a soft tissue or bony sarcoma, breast cancer, brain tumor, adrenal cortical carcinoma, or leukemia. However, with larger epidemiological studies, it is now apparent that affected families may have a much broader range of malignancies and age of onset, with rare individuals even remaining tumor free and experiencing longevity, highlighting the complexity of the TP53 tumor-suppressor network (Kamihara et al. 2014). In an informative example, a cluster of cases of childhood adrenal cortical carcinoma observed in Southern Brazil (Ribeiro et al. 2001; Achatz et al. 2007) led to the discovery of a mutation, $\mathrm{R} 337 \mathrm{H}$, that results in pH-dependent instability of the TP53 tetramer (DiGiammarino et al. 2002) and tissue-restricted tumor development. The study of human disease continues to provide important insight into the function of the TP53 protein.

The accumulated knowledge of the TP53 tumor-suppressor function from more than $30 \mathrm{yr}$ of research has culminated in its exploitation for the treatment of human cancer. Targeted therapies aimed at specifically increasing, or restoring, TP53 function have proven effective in eliciting tumor regression in preclinical models, for example, by using small molecule inhibitors that block the E3 ubiquitin ligase, MDM2 (HDM2), which is the major negative regulator of TP53 (Vassilev 2005; Brown et al. 2009).

\section{REQUIREMENTS FOR TP53-MEDIATED TUMOR SUPPRESSION}

\section{Detection and Response to Oncogenic Stress}

The TP53 tumor suppressor can be activated by diverse cellular stresses, including oncogene expression, DNA damage, hypoxia, metabolic dysfunction, and replicative stress, following which it implements appropriate responses to oppose cancer initiation. Activation of the TP53 protein may result in a variety of cellular responses, including apoptosis, cell senescence, cell-cycle arrest, DNA repair, metabolic adaptations, and changes to cellular characteristics, such as differentiation state. The fate of the cell following TP53 activation is determined by the type, duration, and amplitude of the stress signal as well as the context in which it occurs, such as the cell type. The outcome is modulated by the interplay with other signaling pathways that are active. In addition, the TP53 protein exerts substantial control over cellular homeostasis in the steady state, even before "activation" by stress signals. Control of TP53 activity is achieved through an elaborate system of posttranslational modifications, including phosphorylation, acetylation, and ubiquitination, which impact TP53 protein binding to specific sites in the DNA, protein turnover, and interaction with other proteins that affect TP53 protein transcriptional function (Kruse and Gu 2009). Furthermore, there may be an additional role for the regulation of TP53 protein activity according to the levels and sites of Tp53 gene expression. The TP53 protein, therefore, lies at the convergence of a diverse range of signaling processes that communicate the cell state (Fig. 1). These signals are then integrated to elicit a protective TP53-mediated response; the dynamic regulation and activation of TP53 protein function is critical for effective tumor suppression.

\section{Tumor Suppression and Transcriptional Regulation}

Following activation, the TP53 protein functions predominantly as a transcription factor (Riley et al. 2008). The TP53 protein forms a homotetramer (Friedman et al. 1993) that binds to specific $T p 53$ response elements in genomic DNA (el-Deiry et al. 1992; Cho et al. 1994) to direct the transcription of a large number of protein-coding genes (Riley et al. 2008). The requirement for TP53 transcriptional activity in tumor suppression has been examined by systematically mutating the transactivation domains of the TP53 protein, rendering it either partially or wholly transcriptionally defective (Brady et al. 2011; Jiang et al. 2011). Importantly, mutations resulting in complete loss of TP53 transcriptional activity ablate its ability to prevent tumor formation, supporting the con- 
B.J. Aubrey et al.

\section{Basal TP53 activity}

A $\operatorname{Hdm} 2(\mathrm{Mdm} 2)$

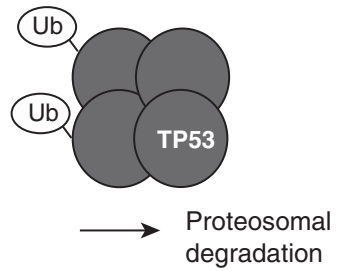

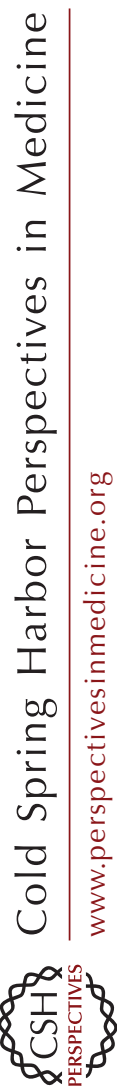

\section{B Transcriptional repression}

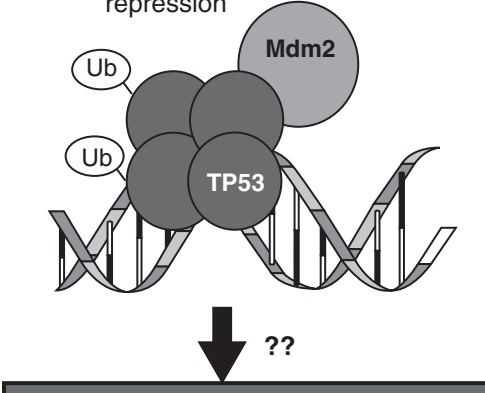
phosphorylation $(\mathrm{P})$.
Stress-induced TP53 activation

C
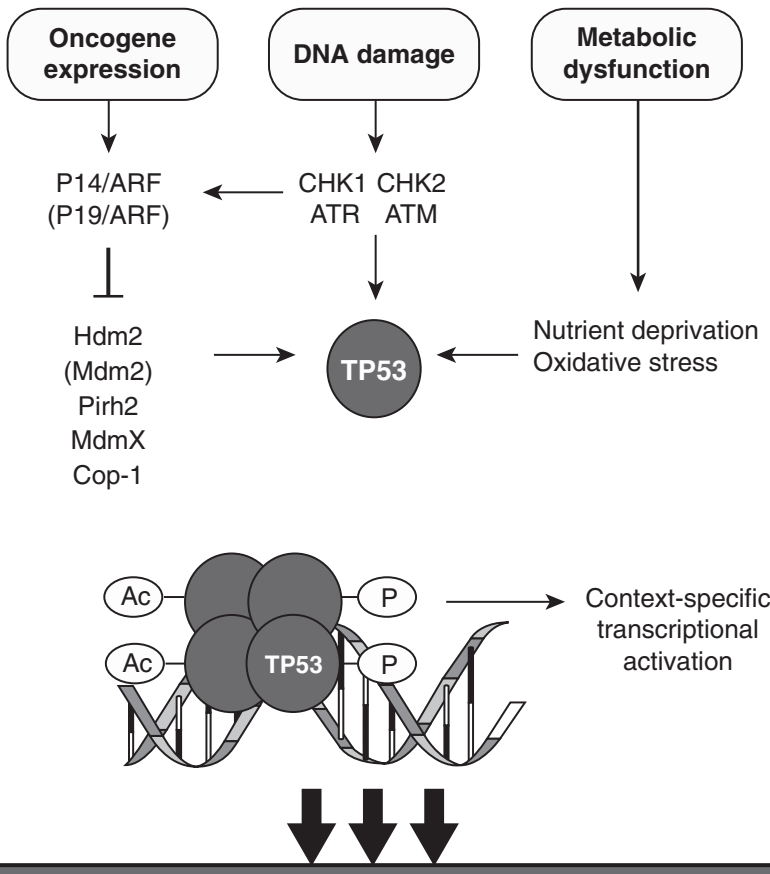

Tumor suppression

Figure 1. Appropriate activation and feedback control of TP53 activity is critical to effective tumor suppression. (A) In the absence of a TP53-activating signal, TP53 protein levels are maintained at low levels in most cell types by the E3 ubiquitin ligase, MDM2 (HDM2), which ubiquitinates (Ub) TP53 and targets it for degradation by the proteosome. $(B)$ The TP53 protein may also control gene expression in the absence of an activating stimulus, for example, by transcriptional repression. The extent to which basal TP53 activities contribute to the tumorsuppressor function is not known. $(C)$ Stress stimuli, such as oncogene expression, DNA damage, and metabolic dysfunction, rapidly lead to TP53 protein accumulation and activation; this is in part owing to inhibition of MDM2 (HDM2), thus preventing TP53 ubiquitination and proteosomal degradation. Following activation, the TP53 protein acts as a sequence-specific transcription factor directing the expression of a large number of target genes, which are considered the primary determinants of the tumor-suppressor response. The specific mode of the TP53 response is influenced by extensive posttranslational modification, including acetylation (Ac) and

cept that transcriptional regulation is central to the tumor-suppressor function. Nontranscriptional functions for the TP53 protein have been proposed; however, their biological importance remains uncertain (Vousden and Lane 2007). The majority of evidence suggests that TP53-mediated tumor suppression is governed by transcriptional regulation; therefore, understanding the critical TP53 gene targets and mechanisms of their transcriptional regulation is a key objective.
TP53-mediated transcriptional regulation varies according to the type of stress stimulus and type of cell, so that appropriate corrective processes can be implemented. For example, minor DNA damage may institute cell-cycle arrest and activate DNA-repair mechanisms, whereas stronger TP53-activating signals induce senescence or apoptosis. Accordingly, the TP53 transcriptional response varies depending on the nature of the activating signal and the type of cell; the detailed mechanisms underly- 
ing these differences in transcriptional induction of target genes remain unknown. However, unprecedented insight into this process has been gained through the analysis of TP53 protein DNA binding and transcriptional regulation using next-generation techniques, such as chromatin immunoprecipitation (ChIP) DNA and RNA sequencing. The number of known or suspected TP53 target genes has increased into the thousands with dramatic differences in transcriptional responses observed among different cell types, different TP53-inducing stress stimuli, and varying time points following TP53 activation (Allen et al. 2014). These studies paint an increasingly complex picture of the modes by which TP53 can regulate gene expression. For example, before TP53 activation, a subset of target genes is transcriptionally repressed by the TP53 protein (Allen et al. 2014). More recently appreciated functions of the TP53 protein include widespread binding and modulation of enhancer regions throughout the genome and transcriptional activation of noncoding RNAs (He et al. 2007; Younger et al. 2015). Interestingly, the TP53-activated long noncoding RNA, lincRNA-p21, exerts widespread suppression of gene expression (Huarte et al. 2010). The list of proposed TP53 target genes is vast and they are known to influence diverse cellular processes, including apoptosis, cell-cycle arrest, senescence, DNA-damage repair, metabolism, and global regulation of gene expression, each of which could potentially contribute to its tumor-suppressor function (Fig. 2).

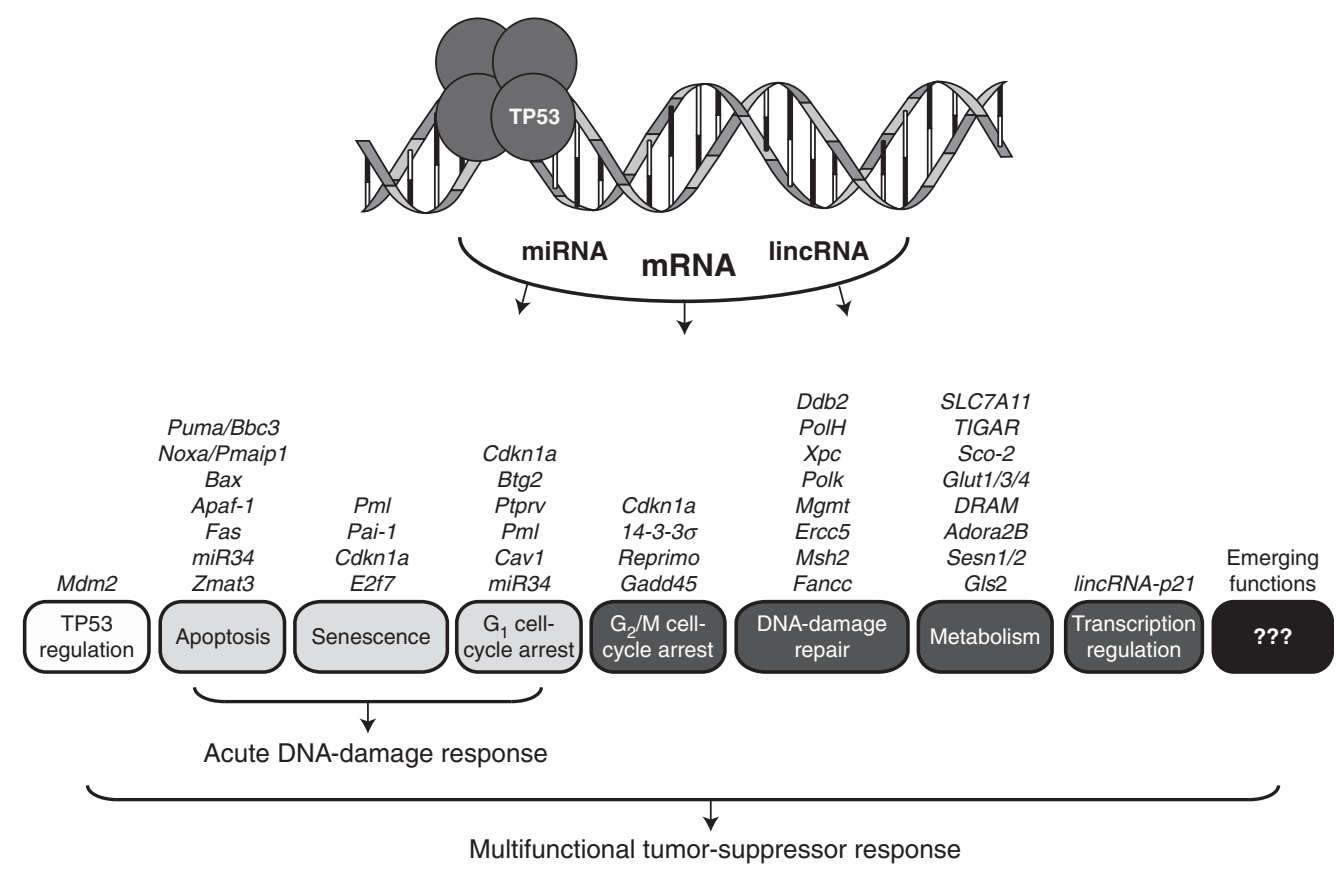

Figure 2. The TP53 protein exerts its tumor-suppressor function as a sequence-specific transcription factor. Following activation, the TP53 protein directs the expression of a large number of genes encoding mRNA, miRNA, and lincRNAs that orchestrate a variety of cellular processes. In addition, TP53 may have as yet undetermined effector functions that are important for tumor suppression. It is increasingly apparent that a single effector function is inadequate to explain the potency and complexity of TP53's tumor-suppressor function. In contrast, specific effector functions may be more or less important depending on the context and multiple effector pathways are likely to collaborate and synergize in the prevention and suppression of tumor formation. Selected TP53-regulated murine genes are shown with their associated cellular processes (some genes may impact on various pathways, e.g., CDKN1a [p21], which is critical for $\mathrm{G}_{1}$ cell-cycle arrest and cell senescence). 
B.J. Aubrey et al.

Insight into the critical TP53 transcriptional targets has been gained from genetic mouse models expressing transcriptionally defective mutant TP53 proteins. Interestingly, a partially transactivation defective TP53 protein, denoted TP53 ${ }^{25,26}$ (Brady et al. 2011), can only activate a limited number of TP53 target genes and is unable to induce apoptosis, cell-cycle arrest, or senescence, yet it retains the ability to suppress tumor formation. Complementary findings have been observed in a different mouse model, in which key lysine residues of the TP53 protein, which are modified by acetylation during posttranslational activation, have been mutated to arginine, denoted $\mathrm{TP} 53^{3 \mathrm{KR}}$ (Li et al. 2012). Similar to the TP53 $3^{25,26}$ mutant, the mutant TP53 ${ }^{3 \mathrm{KR}}$ protein is unable to activate target genes that mediate apoptosis, cell-cycle arrest, and cell senescence, yet it still retains the ability to suppress tumor development. Examination of these mutant strains of mice revealed preserved regulation of several TP53 response genes involved in DNA-damage repair and metabolism, implicating a potentially critical role for these processes in tumor suppression. At present, the search for the critical TP53 tumorsuppressor transcriptional targets is underway in earnest.

\section{KEY EFFECTOR FUNCTIONS FOR TUMOR SUPPRESSION}

\section{Apoptosis}

Apoptosis was one of the earliest identified components of the TP53-mediated tumor-suppressor response (Yonish-Rouach et al. 1991). Induction of apoptosis is among the most extensively studied cellular processes activated by the TP53 protein and has been the focus of much of the investigation into its tumor-suppressor effect. Impaired apoptosis is a cardinal feature of malignancy and genetic alterations that result in evasion from apoptotic cell death markedly accelerate tumor development (Vaux et al. 1988; Strasser et al. 1990; Czabotar et al. 2014). Multiple TP53 target genes have been implicated in TP53-mediated induction of apoptosis: Puma, Noxa, Bax, Apaf1, Fas, Tnfrsf10B/DR5, miR34, TP53AIP1, Pidd, Pig3,
Zmat3, and Siva. Among these target genes, Puma, Noxa, Bax, and Apaf-1 play critical roles in the intrinsic (also called BCL-2-regulated or mitochondrial) apoptotic pathway (Youle and Strasser 2008; Strasser et al. 2011), whereas Fas and Tnfrsf10B/DR5 encode for members of the tumor necrosis factor receptor (TNFR) family (FAS/APO-1/CD95 and TRAIL-R/DR5) that can trigger the death receptor (also called extrinsic) apoptotic pathway (Strasser et al. 2009). Of all these TP53 target genes, only the proapoptotic BH3-only BCL-2 family members PUMA and NOXA have been validated by studies of gene-targeted mice to be essential for TP53-mediated apoptosis (Jeffers et al. 2003; Shibue et al. 2003; Villunger et al. 2003; Michalak et al. 2008). Although the Bax and Apaf-1 genes are also direct TP53 targets (Riley et al. 2008), TP53-deficient cells still express these effectors of apoptosis. Therefore, their induction likely serves to amplify TP53-mediated apoptosis signaling. The miR34 family of microRNAs is a TP53 target (He et al. 2007) predicted to exert broad antioncogenic effects through the posttranscriptional regulation of a variety of genes that not only sensitize to apoptosis, for example, by down-regulation of BCL-2 (Bommer et al. 2007), but also through regulation of cell-cycle progression and differentiation. Surprisingly, however, mice that are deficient of all miR34 family members are not susceptible to spontaneous or oncogene-induced tumor development (Concepcion et al. 2012). Importantly, the death receptor apoptotic pathway is dispensable for TP53-induced apoptosis (Newton and Strasser 2000). However, TP53-mediated induction of Fas and Tnfrsf10B/DR5 expression may serve to sensitize stressed cells to the death receptor ligands, FASL and TRAIL, and it has been proposed that this could be exploited for cancer therapy (Ashkenazi 2008).

The role of TP53-mediated apoptosis in preventing oncogene-driven cancer development has been defined using the $E \mu$-Myc transgenic mouse model (Adams et al. 1985). Here the immunoglobulin heavy chain gene enhancer $(\mathrm{E} \mu)$ has been juxtaposed to the $c-M y c$ oncogene, resulting in deregulated c-MYC expression and, consequently, the rapid development of 
pre-B and B-cell lymphomas. In the $E \mu-M y c$ mouse model, spontaneous inactivation of the TP53 pathway, most frequently through mutations in Tp53 itself, is seen in 20\% of lymphomas (Eischen et al. 1999; Schmitt et al. 1999; Michalak et al. 2009), indicative of its critical role in this setting. Accordingly, inactivation of TP53 function markedly accelerates MYC-driven lymphoma development (Schmitt et al. 1999; Michalak et al. 2009). Strikingly, complete deletion of the Tp53 gene using CRISPR/Cas9 targeting in $E \mu-M y c$ hematopoietic stem/progenitor cells (HSPC) results in the rapid development of lymphoma with a median latency of only $29 \mathrm{~d}$ (Aubrey et al. 2015) as compared with nontargeted $E \mu-M y c$ HSPC that give rise to lymphoma with a mean latency of $>110 \mathrm{~d}$. The specific requirement for individual TP53 apoptotic transcriptional targets in the tumorsuppressor function has been dissected using the $E \mu-M y c$ mouse model where loss of BAX (Eischen et al. 2001; Dansen et al. 2006), PUMA, and NOXA (Hemann et al. 2004; Michalak et al. 2009) can each accelerate lymphoma development, although not to the same extent as complete loss of TP53 function. This suggests critical roles for additional pathways in tumor suppression during MYC-driven lymphoma development.

Interestingly, mice engineered to harbor only specific gene knockout of the TP53 apoptotic targets Puma (Jeffers et al. 2003), Noxa (Villunger et al. 2003), Bax (Knudson et al. 2001), or even combined loss of Puma/Noxa/ p21 (Valente et al. 2013) do not display a propensity for tumor formation. Thus, in the absence of constitutive oncogenic stress, the combined knockout of the major TP53-dependent mediators of apoptosis (PUMA and NOXA) and the major mediator of $G_{1} / S$ cell-cycle arrest and cell senescence (p21) does not recapitulate the tumor predisposition observed in Tp53 ${ }^{-/-}$ mice. Apoptosis clearly plays a critical role in tumor suppression; however, additional pathways must be disabled to fully recapitulate the effect from complete loss of TP53. Furthermore, these studies show that the animal model in which TP53 functions is examined will likely influence the experimental findings. Although
PUMA, NOXA, and BAX are important mediators of TP53-induced apoptosis, there may be additional proapoptotic effector mechanisms that have yet to be fully defined. For example, the proapoptotic $\mathrm{BH} 3$-only protein BIM may be induced indirectly by TP53 and contribute to the killing of tumor cells by DNA-damageinducing chemotherapeutic drugs (Happo et al. 2010). Importantly, there is substantial overlap between the regulation of apoptotic cell death and other pathways, such as DNA-damage repair and metabolism; thus, the role of apoptosis in tumor suppression may be intertwined with other TP53-dependent effectors.

\section{Cell-Cycle Regulation and DNA- Damage Repair}

Cancer is a disease that results from the progressive acquisition and accumulation of genetic mutations (Hanahan and Weinberg 2011), and the TP53 protein, as the "guardian of the genome" (Lane 1992), has a salient role in maintaining genomic integrity and opposing this process. The TP53 protein plays an intimate role in the cellular response to DNA damage. It is critical to both the acute phase response involving cell-cycle arrest, senescence, and apoptosis as well as long-term surveillance mechanisms for maintaining multiple DNA-damagerepair mechanisms, such as nucleotide excision repair, base excision repair, and nonhomologous end-joining (Sengupta and Harris 2005).

In many cells, the initial TP53-mediated response to acute DNA damage is the induction of transient $\mathrm{G}_{1}$ cell-cycle arrest, which allows time for the detection and repair of DNA damage before replication of the genome in $\mathrm{S}$ phase and subsequent cell division. The TP53 protein also exerts checkpoint control during the $G_{2} / M$ transition, at which time DNA replication has already occurred and cells prepare to undergo mitotic cell division (Taylor and Stark 2001), a time when failed detection and repair of damaged DNA may be most catastrophic (e.g., resulting in aneuploidy). Both cell-cycle checkpoints are critical to maintaining genomic integrity and the requirement for TP53-mediated cell-cycle arrest in maintaining genomic 
B.J. Aubrey et al.

stability has been shown experimentally (Barboza et al. 2006). The key mediator of TP53induced $\mathrm{G}_{1}$ cell-cycle arrest is thought to be CDKN1a (p21), as shown by cells from Cdkn1a $a^{-/-}$mice that show impaired $\mathrm{G}_{1}$ cellcycle arrest in response to DNA damage and TP53 activation (El-Deiry et al. 1993; Brugarolas et al. 1995; Deng et al. 1995). Given the integral role of cell-cycle arrest in DNA repair, CDKN1a has been proposed to contribute to TP53-mediated tumor suppression. However, mice that lack CDKN1a (p21) are not prone to spontaneous tumor formation (Deng et al. 1995; Valente et al. 2013). Additional TP53 transcriptional targets also contribute to $G_{1}$ phase cell-cycle arrest including, but not limited to, the promyelocytic gene $(P m l)$, protein tyrosine phosphatase receptor type-V gene (Ptprv), Caveolin-1 (Cav1) (Galbiati et al. 2001), and Btg2 (Rouault et al. 1996). In addition, other TP53 targets specifically instigate cell-cycle arrest at the $G_{2} / M$ checkpoint, including the growth-arrest and DNA-damage-inducible $45 \alpha$ gene (Gadd $45 \alpha$ ), Reprimo, and the $14-3-3 \sigma$ protein (Taylor and Stark 2001). The roles of GADD $45 \alpha$, PTPRV, PML, and CAV1 have been examined individually through the generation of knockout mice but none of these animals spontaneously develop cancer (Hollander et al. 1999; Razani et al. 2001; Rego et al. 2001; Doumont et al. 2005). However, similar to other candidate TP53 tumor-suppressor transcriptional targets, their deficiency can accelerate tumor formation under conditions of specific oncogenic stress $(\mathrm{Ca}-$ pozza et al. 2003; Tront et al. 2010).

TP53-induced cell-cycle arrest is thought necessary to allow for appropriate DNA-repair processes to occur (Barboza et al. 2006). Precancerous lesions are characterized by the accumulation of DNA damage and consequent activation of the TP53-mediated DNA-damage response (Bartkova et al. 2005; Gorgoulis et al. 2005). The acquisition of mutations during tumor initiation occurs through a variety of mechanisms including mutations and epigenetic modifications followed by propagation of these alterations owing to defective DNA-damage repair mechanisms. The TP53 protein plays pivotal roles in all of these processes and, in keeping with the importance of TP53 in maintaining genomic stability, cells from $T p 53^{-/-}$ mice as well as TP53-defective human cancers are characterized by widespread genomic alterations. In line with this, TP53 has a large number of direct transcriptional targets that mediate DNA-repair pathways, including Polk, Mgmt, Fancc, Ercc5, Xpc, Ddb2, Gadd45 $\alpha$, Msh2, and PolH (Allen et al. 2014; Bieging et al. 2014). The central role of genomic instability during the evolution of thymic lymphomas in $T p 53^{-/-}$ mice has been directly observed over time, where defective DNA repair results in a very high rate of gene copy number variations, including chromotrypsis-like events, which drive the accumulation of the cooperating genetic lesions required for malignant transformation (Dudgeon et al. 2014). This supports the notion that genomic instability is a key driver of cancer development in the absence of the TP53 protein.

In certain cell types, activation of the TP53 protein can result in the induction of apoptosis resulting in the elimination of irreversibly damaged cells. However, the acute DNA-damage response has been largely excluded from a role in the TP53 tumor-suppressor function through multiple lines of investigation (Christophorou et al. 2006; Brady et al. 2011; Li et al. 2012). The role of the acute DNA-damage response in tumor suppression was evaluated using timed restoration of TP53 protein in $T p 53^{-}$mice following $\gamma$-irradiation to induce thymic lymphoma formation. Remarkably, transient TP53 restoration during the acute DNA-damage response did not produce a tumor-suppressor effect (Christophorou et al. 2006). In contrast, transient restoration of TP53 function that was delayed until after the acute DNA-damage response had ended, at a time when there was no discernable cell-cycle arrest or apoptosis, was sufficient for tumor suppression. Furthermore, the delayed tumor-suppressor function observed is dependent on p19/ARF, implicating oncogene-mediated TP53 activation in nascent neoplastic cells in this response. This is further confirmed through studies of transcriptionally defective and acetylation defective mutant TP53 proteins that are unable to activate the acute DNA-damage response yet retain potent tu- 
mor-suppressor function (Brady et al. 2011; Li et al. 2012). Therefore, the acute pathological DNA-damage response appears to be dispensable for tumor suppression, a remarkable finding that also has major implications for cancer therapy.

The consequences of oncogene overexpression are twofold in the setting of DNA damage and TP53-mediated tumor suppression. First, acquired mutations may result in the activation of oncogenes, and cells expressing oncogenes can be selected for through enhanced proliferation and cell survival. Second, chronic oncogene activation drives abnormal cell growth, thereby increasing the risk of acquiring additional DNA lesions that may activate further oncogenes or inactivate tumor-suppressor genes (Halazonetis et al. 2008). TP53 may be purposed to eliminate or growth-arrest cells marked by oncogene overexpression, which is intimately connected with DNA damage, deregulated cell proliferation, and metabolic deregulation.

\section{Senescence}

Induction of cell senescence was first shown to play a critical role in TP53-mediated tumor suppression in a mouse model of erythroleukemia (Metz et al. 1995). Moreover, restoration of TP53 function in established solid-organ tumors (driven by loss of TP53) in vivo leads to the induction of cellular senescence in association with tumor regression (Ventura et al. 2007; Xue et al. 2007). Cellular senescence is a distinct cell state involving permanent cell-cycle arrest of cells that remain viable and metabolically active, which is characterized by a discrete transcriptional profile (Shay and Roninson 2004). The TP53 protein controls cellular senescence by activating a number of transcriptional targets that include Cdkn1a, Pml, Pail, and E2f7 (Pearson et al. 2000; Kortlever et al. 2006; Aksoy et al. 2012), some of which (e.g., Cdkn1a) are notable for additional function in cell-cycle regulation. Senescence is often associated with, and is thought to suppress, premalignant lesions preventing their progression to overt malignancy (Collado et al. 2005; Mooi and Peeper 2006). TP53-mediated induction of cell senescence was shown to be critical to preventing malignant transformation in a mouse model of BRAFdriven pulmonary adenoma (Dankort et al. 2007). Moreover, in a study examining the functional interdependence of defects in PTEN and TP53 in the development of prostate carcinoma, TP53-mediated senescence was required to prevent cancer development in the setting of PTEN deletion (Chen et al. 2005). It remains to be examined whether complete loss of all target genes implicated in TP53-mediated senescence can recapitulate the spontaneous tumor development seen in $T p 53^{-/-}$mice and whether the strong association between senescence and tumor suppression is causal or whether this is an association with other TP53-mediated effects.

\section{Metabolism}

The rapid proliferation of cells, anabolic growth, and metabolic stress that typifies neoplastic disease requires substantial metabolic reprogramming (Hanahan and Weinberg 2011). Furthermore, metabolic deregulation not only impacts on energy production and cell growth but also influences additional processes important to sustained cancer growth, such as macromolecular biosynthesis, epigenetic regulation, and antioxidant pathways (Cairns et al. 2011; Ward and Thompson 2012). The TP53 protein is a critical regulator of cellular metabolism and many of the aforementioned processes affected by metabolic stress (Berkers et al. 2013).

The best-characterized description of cancer-associated metabolic reprogramming is the Warburg effect, whereby glucose is predominantly metabolized by glycolysis rather than oxidative phosphorylation, as normally occurs under aerobic conditions (Warburg 1956). TP53 activation stimulates oxidative phosphorylation and inhibits glycolysis, both of which oppose the Warburg effect. The TP53 protein can regulate the expression of several glucose transporters, including GLUT1, GLUT3, and GLUT4 (Schwartzenberg-Bar-Yoseph et al. 2004; Kawauchi et al. 2008), which diminishes glycolysis through impaired glucose uptake. TP53 also transactivates the TP53-induced glycolysis and apoptosis regulator gene (TIGAR), which en- 
B.J. Aubrey et al.

codes a fructose phosphatase enzyme that inhibits glycolysis and increases production of NADPH (Bensaad et al. 2006). NADPH is important for the scavenging of reactive oxygen species (ROS), and this antioxidant effect of TIGAR confers a prosurvival function in the setting of ROS-mediated cell death. However, TIGAR knockout mice do not show spontaneous tumor formation (Cheung et al. 2013) and, in some contexts, TIGAR deficiency actually impedes tumor development (Bensaad et al. 2006). TP53 also directly stimulates mitochondrial oxidative phosphorylation through transcriptional activation of the gene-encoding synthesis of cytochrome $c$ oxidase 2 (Sco2) (Matoba et al. 2006). Interestingly, dysregulated oxidative phosphorylation has been observed in cells from patients with $\mathrm{Li}$-Fraumeni syndrome, which is attributed partly to altered Sco-2 expression (Wang et al. 2013).

The strict regulation of cellular antioxidant mechanisms is critical to maintaining intracellular signaling pathways and avoiding ROSassociated toxicity. Therefore, dysregulation of these processes can contribute to cancer development (Finkel 2003). Genes encoding enzymes with antioxidant functions, including Gls2, Sestrin 1, and Sestrin 2, have been identified as TP53 transcriptional targets (Budanov et al. 2004; Hu et al. 2010), defining a mechanism by which TP53 can regulate oxidant signaling and manage oxidative stress. Interestingly, treatment of Tp53 knockout mice with antioxidant therapy was reported to delay the onset of tumor formation, implicating a role for limiting the ROS accumulation in TP53-mediated tumor suppression (Sablina et al. 2005).

Cancer-associated metabolic stress and hypoxia can activate distinct cell death pathways through a variety of mechanisms, including the intrinsic apoptotic pathway (Czabotar et al. 2014). TP53 can modulate metabolic stressinduced cell death through a number of mechanisms. For example, the TP53 protein drives expression of the $A D O R A 2 B$ gene, which can detect nutrient availability and sensitize cells to PUMA-mediated apoptotic cell death (Long et al. 2013). In addition, a recently described form of iron-dependent, nonapoptotic cell death, denoted ferroptosis, is initiated under conditions of metabolic stress and accumulated ROS (Dixon et al. 2012). It has been proposed that TP53 mediates tumor suppression through transcriptional repression of the SLC7A11 gene, which encodes a cystine/glutamate antiporter that diminishes cellular predisposition to ferroptosis (Jiang et al. 2015).

Finally, autophagy is another TP53-regulated metabolic process that may contribute to tumor suppression (Maiuri et al. 2010; Kenzelmann Broz et al. 2013). Autophagy enables cells to adapt and survive in conditions of limiting nutrient availability by recycling intracellular contents, such as damaged proteins and organelles for the purpose of liberating energy and metabolites to maintain cellular integrity (Mathew and White 2011). Autophagy may further impact on tumor suppression by affecting apoptotic pathways and genomic stability. TP53 regulates autophagy at multiple levels (Feng et al. 2005) by transactivating a large number of genes (Kenzelmann Broz et al. 2013), including the genes encoding damage-associated autophagy mediator (DRAM) (Crighton et al. 2006) and ULK1 (Gao et al. 2011). Interestingly, siRNAmediated knockdown of DRAM was shown to reduce TP53-dependent apoptosis (Crighton et al. 2006).

\section{EMERGING TP53 FUNCTIONS AND TUMOR SUPPRESSION}

New components of the TP53 response continue to emerge and many of these have been implicated in tumor suppression (Bieging et al. 2014; Hager and Gu 2014). These include roles for TP53 in stem-cell function, differentiation, cellular invasion, and metastasis, as well as regulation of the immune response and the tumor microenvironment. For example, in a mouse model of hepatocellular carcinoma, TP53 was shown to influence the microenvironment and immune response via a non-tumor-cell-autonomous mechanism, which impacted the rate of tumor expansion and aggressiveness (Lujambio et al. 2013). These emerging functions have as yet undetermined roles in tumor suppression; however, they highlight the increasingly 
complex picture of the role of TP53 in cancer biology.

In addition to newly identified functions for the TP53 protein, novel approaches to understanding the mechanisms of tumor suppression are emerging. Cell competition has recently been established as a bona fide mechanism for tumor suppression (Martins et al. 2014) when it was shown that disruption of normal cell competition in the thymus leads to the formation of acute T-lymphoblastic leukemia. The concept of cell competition provides a view of the overall fitness of cells as they compete within a larger population of cells, accounting for various cellular attributes as well as context-dependent factors. In studies of hematopoietic progenitor cells, the TP53 protein was shown to mediate cell competition (Bondar and Medzhitov 2010), raising the possibility that cell competition may be an important framework within which to approach the question of TP53-mediated tumor suppression.

\section{DISTINCTIONS BETWEEN HUMAN CANCER AND MOUSE MODELS}

It is important to recognize a number of key distinctions between findings from mouse models and human disease. In human cancer, inactivation of the TP53 gene almost always occurs by acquisition of a missense mutation rather than deletion of the TP53 gene. Furthermore, these mutations frequently result in a single amino acid substitution and the production of a stable, overexpressed TP53 protein that can actively contribute to tumor development and growth over and above the consequences of losing wild-type TP53 function alone (Freed-Pastor and Prives 2012). In addition, the initial acquisition of Tp53 mutations is usually followed by loss of heterozygosity, which typically involves large deletions of the short arm of chromosome 17 (17p). The large chromosomal deletion results in the loss of several additional genes and this raises the possibility that cooperating lesions on $17 \mathrm{p}$ may contribute to human cancers. For example, a gene encoding a component of the RNA polymerase II complex, POLR2A, is almost always codeleted in human cancers with the TP53 gene, and this has functional impact on the resulting tumor (Liu et al. 2015). These are important features of human cancer that are inextricable from the question of understanding how loss or mutation of TP53 leads to the development of cancer.

\section{CONCLUDING REMARKS}

The tumor-suppressor function of the TP53 protein is likely to be mediated through a number of collaborating effector functions rather than through a single pathway or single transcriptional target. Understanding how these mechanisms work together will require creative approaches to investigation that take into account the combinatorial nature and complexity of the TP53 response as well as consideration of its functioning in normal cellular processes. It is an intriguing question as to whether the primary purpose of the TP53 protein is tumor suppression or whether this is a secondary manifestation of its many important roles in normal biology. For example, the importance of the TP53 protein in maintaining genomic stability extends beyond the prevention of cancer to being a basic requirement for sustainable life that ensures an organism's genetic material is transmitted faithfully to subsequent generations (Jackson and Bartek 2009; Kerr et al. 2012) and speaks to the evolutionary conservation of the $T p 53$ family of genes from the earliest multicellular organisms to humans (Belyi et al. 2010; Lane et al. 2010). Another important consideration is that TP53 contributes to normal cellular processes that may also be important in established tumors. For example, TP53 facilitates adaptation to some forms of metabolic stress, such as serine deprivation, whereby $T p 53^{-/-}$ cells are actually disadvantaged (Maddocks et al. 2013). As such, the complete loss of TP53 function during cancer initiation may not be entirely advantageous and such vulnerabilities may be exploited for treatment of TP53-deficient cancers. Understanding the role of TP53 in tumor suppression remains one of the most exciting and important biological questions that promises exciting advances for the next 30 years of TP53 research. 
B.J. Aubrey et al.

\section{ACKNOWLEDGMENTS}

The authors thank Drs. Marco J. Herold, Daniel H.D. Gray, Jerry M. Adams, Suzanne Cory, and Ana Janic for insightful discussions and advice, and Cameron Wells and Rachel Bucknall for assistance with graphic design. This work is supported by a Leukaemia Foundation National Research Program Clinical PhD Scholarship (B.J.A.), a Kay Kendall Leukaemia Fund Intermediate Fellowship (KKL331 to G.L.K.), a National Health and Medical Research Council, Australia, Program Grant 1016701 (A.S.) and Fellowship 1020363 (A.S.), Project Grant 1086291 from the National Health and Medical Research Council, Australia (G.L.K.), a Cancer Council Victoria Grant-in-Aid 1086157 (G.L.K), and a Leukemia and Lymphoma Society SCOR Grant 7001-13 (A.S.). This work is made possible through Victorian State Government Operational Infrastructure Support and Australian Government National Health and Medical Research Council Independent Research Institutes Infrastructure Support Scheme.

\section{REFERENCES}

Achatz MI, Olivier M, Le Calvez F, Martel-Planche G, Lopes A, Rossi BM, Ashton-Prolla P, Giugliani R, Palmero EI, Vargas FR, et al. 2007. The TP53 mutation, R337H, is associated with $\mathrm{Li}$-Fraumeni and $\mathrm{Li}-$ Fraumeni-like syndromes in Brazilian families. Cancer Lett 245: 96-102.

Adams JM, Harris AW, Pinkert CA, Corcoran LM, Alexander WS, Cory S, Palmiter RD, Brinster RL. 1985. The c-myc oncogene driven by immunoglobulin enhancers induces lymphoid malignancy in transgenic mice. Nature 318: 533-538.

Aksoy O, Chicas A, Zeng T, Zhao Z, McCurrach M, Wang X, Lowe SW. 2012. The atypical E2F family member E2F7 couples the p53 and RB pathways during cellular senescence. Genes Dev 26: 1546-1557.

Allen MA, Andrysik Z, Dengler VL, Mellert HS, Guarnieri A, Freeman JA, Sullivan KD, Galbraith MD, Luo X, Kraus WL, et al. 2014. Global analysis of p53-regulated transcription identifies its direct targets and unexpected regulatory mechanisms. eLife 3: e02200.

Ashkenazi A. 2008. Directing cancer cells to self-destruct with pro-apoptotic receptor agonists. Nat Rev Drug Discov 7: 1001-1012.

Aubrey BJ, Kelly GL, Kueh AJ, Brennan MS, O'Connor L, Milla L, Wilcox S, Tai L, Strasser A, Herold MJ. 2015. An inducible lentiviral guide RNA platform enables the identification of tumor-essential genes and tumor-promoting mutations in vivo. Cell Rep 10: 1422-1432.
Baker SJ, Fearon ER, Nigro JM, Hamilton SR, Preisinger AC, Jessup JM, vanTuinen P, Ledbetter DH, Barker DF, Nakamura Y, et al. 1989. Chromosome 17 deletions and p53 gene mutations in colorectal carcinomas. Science 244: 217-221.

Barboza JA, Liu G, Ju Z, El-Naggar AK, Lozano G. 2006.p21 delays tumor onset by preservation of chromosomal stability. Proc Natl Acad Sci 103: 19842-19847.

Bartkova J, Horejsi Z, Koed K, Kramer A, Tort F, Zieger K, Guldberg P, Sehested M, Nesland JM, Lukas C, et al. 2005. DNA damage response as a candidate anti-cancer barrier in early human tumorigenesis. Nature 434: 864-870.

Belyi VA, Ak P, Markert E, Wang H, Hu W, Puzio-Kuter A, Levine AJ. 2010. The origins and evolution of the p53 family of genes. Cold Spring Harb Perspect Biol 2: a001198.

Bensaad K, Tsuruta A, Selak MA, Vidal MN, Nakano K, Bartrons R, Gottlieb E, Vousden KH. 2006. TIGAR, a p53-inducible regulator of glycolysis and apoptosis. Cell 126: $107-120$.

Berkers CR, Maddocks OD, Cheung EC, Mor I, Vousden KH. 2013. Metabolic regulation by p53 family members. Cell Metab 18: 617-633.

Bieging KT, Mello SS, Attardi LD. 2014. Unravelling mechanisms of p53-mediated tumour suppression. Nat Rev Cancer 14: $359-370$

Bommer GT, Gerin I, Feng Y, Kaczorowski AJ, Kuick R, Love RE, Zhai Y, Giordano TJ, Qin ZS, Moore BB, et al. 2007. p53-mediated activation of miRNA34 candidate tumorsuppressor genes. Curr Biol 17: 1298-1307.

Bondar T, Medzhitov R. 2010. p53-mediated hematopoietic stem and progenitor cell competition. Cell Stem Cell 6: 309-322.

Brady CA, Jiang D, Mello SS, Johnson TM, Jarvis LA, Kozak MM, Kenzelmann Broz D, Basak S, Park EJ, McLaughlin ME, et al. 2011. Distinct p53 transcriptional programs dictate acute DNA-damage responses and tumor suppression. Cell 145: 571-583.

Brown CJ, Lain S, Verma CS, Fersht AR, Lane DP. 2009. Awakening guardian angels: Drugging the p53 pathway. Nat Rev Cancer 9: 862-873.

Brugarolas J, Chandrasekaran C, Gordon JI, Beach D, Jacks T, Hannon GJ. 1995. Radiation-induced cell cycle arrest compromised by p21 deficiency. Nature 377: 552-557.

Budanov AV, Sablina AA, Feinstein E, Koonin EV, Chumakov PM. 2004. Regeneration of peroxiredoxins by p53-regulated sestrins, homologs of bacterial AhpD. Science 304: 596-600.

Cairns RA, Harris IS, Mak TW. 2011. Regulation of cancer cell metabolism. Nat Rev Cancer 11: 85-95.

Capozza F, Williams TM, Schubert W, McClain S, Bouzahzah B, Sotgia F, Lisanti MP. 2003. Absence of caveolin-1 sensitizes mouse skin to carcinogen-induced epidermal hyperplasia and tumor formation. Am J Pathol 162: 2029-2039.

Chen Z, Trotman LC, Shaffer D, Lin HK, Dotan ZA, Niki M, Koutcher JA, Scher HI, Ludwig T, Gerald W, et al. 2005 Crucial role of p53-dependent cellular senescence in suppression of Pten-deficient tumorigenesis. Nature 436: 725-730. 
Cheung EC, Athineos D, Lee P, Ridgway RA, Lambie W, Nixon C, Strathdee D, Blyth K, Sansom OJ, Vousden KH. 2013. TIGAR is required for efficient intestinal regeneration and tumorigenesis. Dev Cell 25: 463-477.

Cho Y, Gorina S, Jeffrey PD, Pavletich NP. 1994. Crystal structure of a p53 tumor suppressor-DNA complex: Understanding tumorigenic mutations. Science 265: 346355.

Christophorou MA, Ringshausen I, Finch AJ, Swigart LB, Evan GI. 2006. The pathological response to DNA damage does not contribute to p53-mediated tumour suppression. Nature 443: 214-217.

Collado M, Gil J, Efeyan A, Guerra C, Schuhmacher AJ, Barradas M, Benguria A, Zaballos A, Flores JM, Barbacid M, et al. 2005. Tumour biology: Senescence in premalignant tumours. Nature 436: 642.

Concepcion CP, Han YC, Mu P, Bonetti C, Yao E, D’Andrea A, Vidigal JA, Maughan WP, Ogrodowski P, Ventura A. 2012. Intact p53-dependent responses in miR-34-deficient mice. PLoS Genet 8: e1002797.

Crighton D, Wilkinson S, O'Prey J, Syed N, Smith P, Harrison PR, Gasco M, Garrone O, Crook T, Ryan KM. 2006. DRAM, a p53-induced modulator of autophagy, is critical for apoptosis. Cell 126: 121-134.

Czabotar PE, Lessene G, Strasser A, Adams JM. 2014. Control of apoptosis by the BCL-2 protein family: Implications for physiology and therapy. Nat Rev Mol Cell Biol 15: 49-63.

Dankort D, Filenova E, Collado M, Serrano M, Jones K, McMahon M. 2007. A new mouse model to explore the initiation, progression, and therapy of BRAFV600E-induced lung tumors. Genes Dev 21: 379-384.

Dansen TB, Whitfield J, Rostker F, Brown-Swigart L, Evan GI. 2006. Specific requirement for bax, not bak, in MYCinduced apoptosis and tumor suppression in vivo. J Biol Chem 281: 10890-10895.

DeLeo AB, Jay G, Appella E, Dubois GC, Law LW, Old LJ. 1979. Detection of a transformation-related antigen in chemically induced sarcomas and other transformed cells of the mouse. Proc Natl Acad Sci 76: 2420-2424.

Deng C, Zhang P, Harper JW, Elledge SJ, Leder P. 1995. Mice lacking p21CIP1/WAF1 undergo normal development, but are defective in $G_{1}$ checkpoint control. Cell 82: 675-684.

DiGiammarino EL, Lee AS, Cadwell C, Zhang W, Bothner B, Ribeiro RC, Zambetti G, Kriwacki RW. 2002. A novel mechanism of tumorigenesis involving $\mathrm{pH}$-dependent destabilization of a mutant p53 tetramer. Nat Struct Biol 9: 12-16.

Dixon SJ, Lemberg KM, Lamprecht MR, Skouta R, Zaitsev EM, Gleason CE, Patel DN, Bauer AJ, Cantley AM, Yang WS, et al. 2012. Ferroptosis: An iron-dependent form of nonapoptotic cell death. Cell 149: 1060-1072.

Donehower LA, Harvey M, Slagle BL, McArthur MJ, Montgomery CAJ, Butel JS, Bradley A. 1992. Mice deficient for p53 are developmentally normal but are susceptible to spontaneous tumours. Nature 356: 215-221.

Doumont G, Martoriati A, Beekman C, Bogaerts S, Mee PJ, Bureau F, Colombo E, Alcalay M, Bellefroid E, Marchesi F et al. 2005. $G_{1}$ checkpoint failure and increased tumor susceptibility in mice lacking the novel p53 target Ptprv. EMBO J 24: 3093-3103.
Dudgeon C, Chan C, Kang W, Sun Y, Emerson R, Robins H, Levine AJ. 2014. The evolution of thymic lymphomas in p53 knockout mice. Genes Dev 28: 2613-2620.

Eischen CM, Weber JD, Roussel MF, Sherr CJ, Cleveland JL. 1999. Disruption of the ARF-Mdm2-p53 tumor suppressor pathway in Myc-induced lymphomagenesis. Genes Dev 13: 2658-2669.

Eischen CM, Roussel MF, Korsmeyer SJ, Cleveland JL. 2001. Bax loss impairs Myc-induced apoptosis and circumvents the selection of p53 mutations during Myc-mediated lymphomagenesis. Mol Cell Biol 21: 7653-7662.

el-Deiry WS, Kern SE, Pietenpol JA, Kinzler KW, Vogelstein B. 1992. Definition of a consensus binding site for p53. Nat Genet 1: 45-49.

el-Deiry WS, Tokino T, Velculescu VE, Levy DB, Parsons R, Trent JM, Lin D, Mercer WE, Kinzler KW, Vogelstein B. 1993. WAF1, a potential mediator of p53 tumor suppression. Cell 75: 817-825.

Eliyahu D, Michalovitz D, Eliyahu S, Pinhasi-Kimhi O, Oren M. 1989. Wild-type p53 can inhibit oncogene-mediated focus formation. Proc Natl Acad Sci 86: 8763-8767.

Feng Z, Zhang H, Levine AJ, Jin S. 2005. The coordinate regulation of the p53 and mTOR pathways in cells. Proc Natl Acad Sci 102: 8204-8209.

Finkel T. 2003. Oxidant signals and oxidative stress. Curr Opin Cell Biol 15: 247-254.

Finlay CA, Hinds PW, Levine AJ. 1989. The p53 proto-oncogene can act as a suppressor of transformation. Cell 57: 1083-1093.

Freed-Pastor WA, Prives C. 2012. Mutant p53: One name, many proteins. Genes Dev 26: 1268-1286.

Friedman PN, Chen X, Bargonetti J, Prives C. 1993. The p53 protein is an unusually shaped tetramer that binds directly to DNA. Proc Natl Acad Sci 90: 3319-3323.

Galbiati F, Volonte D, Liu J, Capozza F, Frank PG, Zhu L, Pestell RG, Lisanti MP. 2001. Caveolin-1 expression negatively regulates cell cycle progression by inducing $\mathrm{G}_{0} / \mathrm{G}_{1}$ arrest via a p53/p21(WAF1/Cip1)-dependent mechanism. Mol Biol Cell 12: 2229-2244.

Gao W, Shen Z, Shang L, Wang X. 2011. Upregulation of human autophagy-initiation kinase ULK1 by tumor suppressor p53 contributes to DNA-damage-induced cell death. Cell Death Differ 18: 1598-1607.

Gorgoulis VG, Vassiliou LV, Karakaidos P, Zacharatos P, Kotsinas A, Liloglou T, Venere M, Ditullio RA Jr, Kastrinakis NG, Levy B, et al. 2005. Activation of the DNA damage checkpoint and genomic instability in human precancerous lesions. Nature 434: 907-913.

Hager KM, Gu W. 2014. Understanding the non-canonical pathways involved in p53-mediated tumor suppression. Carcinogenesis 35: 740-746.

Halazonetis TD, Gorgoulis VG, Bartek J. 2008. An oncogene-induced DNA damage model for cancer development. Science 319: 1352-1355.

Hanahan D, Weinberg RA. 2011. Hallmarks of cancer: The next generation. Cell 144: 646-674.

Happo L, Cragg MS, Phipson B, Haga JM, Jansen ES, Herold MJ, Dewson G, Michalak EM, Vandenberg CJ, Smyth GK, et al. 2010. Maximal killing of lymphoma cells by DNA-damage inducing therapy requires not only the p53 
B.J. Aubrey et al.

targets Puma and Noxa but also Bim. Blood 116: 52565267.

Harvey M, McArthur MJ, Montgomery CA Jr, Bradley A, Donehower LA. 1993a. Genetic background alters the spectrum of tumors that develop in p53-deficient mice. FASEB J 7: 938-943.

Harvey M, McArthur MJ, Montgomery CAJ, Butel JS, Bradley A, Donehower LA. 1993b. Spontaneous and carcinogen-induced tumorigenesis in p53-deficient mice. Nat Genet 5: 225-229.

He L, He X, Lim LP, de Stanchina E, Xuan Z, Liang Y, Xue W, Zender L, Magnus J, Ridzon D, et al. 2007. A microRNA component of the p53 tumour suppressor network. $\mathrm{Na}$ ture 447: 1130-1134.

Hemann MT, Zilfou JT, Zhao Z, Burgess DJ, Hannon GJ, Lowe SW. 2004. Suppression of tumorigenesis by the p53 target PUMA. Proc Natl Acad Sci 101: 9333-9338.

Hollander MC, Sheikh MS, Bulavin DV, Lundgren K, Augeri-Henmueller L, Shehee R, Molinaro TA, Kim KE, Tolosa E, Ashwell JD, et al. 1999. Genomic instability in Gadd45a-deficient mice. Nat Genet 23: 176-184.

Hu W, Zhang C, Wu R, Sun Y, Levine A, Feng Z. 2010. Glutaminase 2, a novel p53 target gene regulating energy metabolism and antioxidant function. Proc Natl Acad Sci 107: 7455-7460.

Huarte M, Guttman M, Feldser D, Garber M, Koziol MJ, Kenzelmann-Broz D, Khalil AM, Zuk O, Amit I, Rabani $\mathrm{M}$, et al. 2010. A large intergenic noncoding RNA induced by p53 mediates global gene repression in the p53 response. Cell 142: 409-419.

Jacks T, Remington L, Williams BO, Schmitt EM, Halachmi S, Bronson RT, Weinberg RA. 1994. Tumor spectrum analysis in p53-mutant mice. Curr Biol 4: 1-7.

Jackson SP, Bartek J. 2009. The DNA-damage response in human biology and disease. Nature 461: 1071-1078.

Jeffers JR, Parganas E, Lee Y, Yang C, Wang J, Brennan J, MacLean KH, Han J, Chittenden T, Ihle JN, et al. 2003. Puma is an essential mediator of p53-dependent and -independent apoptotic pathways. Cancer Cell 4: 321328.

Jiang D, Brady CA, Johnson TM, Lee EY, Park EJ, Scott MP, Attardi LD. 2011. Full p53 transcriptional activation potential is dispensable for tumor suppression in diverse lineages. Proc Natl Acad Sci 108: 17123-17128.

Jiang L, Kon N, Li T, Wang SJ, Su T, Hibshoosh H, Baer R, Gu W. 2015. Ferroptosis as a p53-mediated activity during tumour suppression. Nature 520: 57-62.

Junttila MR, Karnezis AN, Garcia D, Madriles F, Kortlever RM, Rostker F, Brown Swigart L, Pham DM, Seo Y, Evan GI, et al. 2010. Selective activation of p53-mediated tumour suppression in high-grade tumours. Nature 468: 567-571.

Kamihara J, Rana HQ, Garber JE. 2014. Germline TP53 mutations and the changing landscape of $\mathrm{Li}-$ Fraumeni syndrome. Hum Mutat 35: 654-662.

Kawauchi K, Araki K, Tobiume K, Tanaka N. 2008. p53 regulates glucose metabolism through an IKK-NF- $\mathrm{KB}$ pathway and inhibits cell transformation. Nat Cell Biol 10: 611-618.
Kemp CJ, Wheldon T, Balmain A. 1994. p53-deficient mice are extremely susceptible to radiation-induced tumorigenesis. Nat Genet 8: 66-69.

Kenzelmann Broz D, Spano Mello S, Bieging KT, Jiang D, Dusek RL, Brady CA, Sidow A, Attardi LD. 2013. Global genomic profiling reveals an extensive p53-regulated autophagy program contributing to key p53 responses. Genes Dev 27: 1016-1031.

Kerr JB, Hutt KJ, Michalak EM, Cook M, Vandenberg CJ, Liew SH, Bouillet P, Mills A, Scott CL, Findlay JK, et al. 2012. DNA-damage-induced primordial follicle oocyte apoptosis and loss of fertility require TAp63mediated induction of Puma and Noxa. Mol Cell 48: $343-352$.

Knudson CM, Johnson GM, Lin Y, Korsmeyer SJ. 2001. Bax accelerates tumorigenesis in $p 53$-deficient mice. Cancer Res 61: 659-665.

Kortlever RM, Higgins PJ, Bernards R. 2006. Plasminogen activator inhibitor-1 is a critical downstream target of p53 in the induction of replicative senescence. Nat Cell Biol 8: 877-884.

Kruse JP, Gu W. 2009. Modes of p53 regulation. Cell 137: 609-622.

Lane DP. 1992. p53, guardian of the genome. Nature 358: $15-16$.

Lane DP, Crawford LV. 1979. T antigen is bound to a host protein in SV40-transformed cells. Nature 278: 261-263.

Lane DP, Cheok CF, Brown C, Madhumalar A, Ghadessy FJ, Verma C. 2010. Mdm2 and p53 are highly conserved from placozoans to man. Cell Cycle 9: 540-547.

Lang GA, Iwakuma T, Suh YA, Liu G, Rao VA, Parant JM, Valentin-Vega YA, Terzian T, Caldwell LC, Strong LC, et al. 2004. Gain of function of a p53 hot spot mutation in a mouse model of $\mathrm{Li}-$ Fraumeni syndrome. Cell 119: 861-872.

Levine AJ, Oren M. 2009. The first 30 years of p53: Growing ever more complex. Nat Rev Cancer 9: 749-758.

Li FP, Fraumeni JF Jr. 1969. Soft-tissue sarcomas, breast cancer, and other neoplasms. A familial syndrome? Ann Intern Med 71: 747-752.

Li T, Kon N, Jiang L, Tan M, Ludwig T, Zhao Y, Baer R, Gu W. 2012. Tumor suppression in the absence of p53-mediated cell-cycle arrest, apoptosis, and senescence. Cell 149: 1269-1283.

Linzer DI, Levine AJ. 1979. Characterization of a 54K dalton cellular SV40 tumor antigen present in SV40-transformed cells and uninfected embryonal carcinoma cells. Cell 17: 43-52.

Liu Y, Zhang X, Han C, Wan G, Huang X, Ivan C, Jiang D, Rodriguez-Aguayo C, Lopez-Berestein G, Rao PH, et al 2015. TP53 loss creates therapeutic vulnerability in colorectal cancer. Nature 520: 697-701.

Long JS, Crighton D, O’Prey J, Mackay G, Zheng L, Palmer TM, Gottlieb E, Ryan KM. 2013. Extracellular adenosine sensing - A metabolic cell death priming mechanism downstream of p53. Mol Cell 50: 394-406.

Lujambio A, Akkari L, Simon J, Grace D, Tschaharganeh DF, Bolden JE, Zhao Z, Thapar V, Joyce JA, Krizhanovsky V, et al. 2013. Non-cell-autonomous tumor suppression by p53. Cell 153: 449-460. 
Maddocks OD, Berkers CR, Mason SM, Zheng L, Blyth K, Gottlieb E, Vousden KH. 2013. Serine starvation induces stress and p53-dependent metabolic remodelling in cancer cells. Nature 493: 542-546.

Maiuri MC, Galluzzi L, Morselli E, Kepp O, Malik SA, Kroemer G. 2010. Autophagy regulation by p53. Curr Opin Cell Biol 22: 181-185.

Malkin D, Li FP, Strong LC, Fraumeni JFJ, Nelson CE, Kim DH, Kassel J, Gryka MA, Bischoff FZ, Tainsky MA, et al. 1990. Germ line p53 mutations in a familial syndrome of breast cancer, sarcomas, and other neoplasms. Science 250: $1233-1238$.

Martins CP, Brown-Swigart L, Evan GI. 2006. Modeling the therapeutic efficacy of p53 restoration in tumors. Cell 127: $1323-1334$

Martins VC, Busch K, Juraeva D, Blum C, Ludwig C, Rasche V, Lasitschka F, Mastitsky SE, Brors B, Hielscher T, et al. 2014. Cell competition is a tumour suppressor mechanism in the thymus. Nature 509: 465-470.

Mathew R, White E. 2011. Autophagy, stress, and cancer metabolism: What doesn't kill you makes you stronger. Cold Spring Harb Symp Quant Biol 76: 389-396.

Matoba S, Kang JG, Patino WD, Wragg A, Boehm M, Gavrilova O, Hurley PJ, Bunz F, Hwang PM. 2006. p53 regulates mitochondrial respiration. Science 312: 1650-1653.

Metz T, Harris AW, Adams JM. 1995. Absence of p53 allows direct immortalization of hematopoietic cells by the $m y c$ and raf oncogenes. Cell 82: 29-36.

Michalak EM, Villunger A, Adams JM, Strasser A. 2008. In several cell types the tumour suppressor p53 induces apoptosis largely via Puma but Noxa can contribute. Cell Death Differ 15: 1019-1029.

Michalak EM, Jansen ES, Happo L, Cragg MS, Tai L, Smyth GK, Strasser A, Adams JM, Scott CL. 2009. Puma and to a lesser extent Noxa are suppressors of Myc-induced lymphomagenesis. Cell Death Differ 16: 684-696.

Mooi WJ, Peeper DS. 2006. Oncogene-induced cell senescence-Halting on the road to cancer. N Engl J Med 355: 1037-1046.

Nacht M, Strasser A, Chan YR, Harris AW, Schlissel M, Bronson RT, Jacks T. 1996. Mutations in the p53 and SCID genes cooperate in tumorigenesis. Genes Dev 10: 2055-2066.

Newton K, Strasser A. 2000. Ionizing radiation and chemotherapeutic drugs induce apoptosis in lymphocytes in the absence of fas or FADD/MORT1 signaling: Implications for cancer therapy. J Exp Med 191: 195-200.

Olive KP, Tuveson DA, Ruhe ZC, Yin B, Willis NA, Bronson RT, Crowley D, Jacks T. 2004. Mutant p53 gain of function in two mouse models of Li-Fraumeni syndrome. Cell 119: $847-860$.

Pearson M, Carbone R, Sebastiani C, Cioce M, Fagioli M, Saito S, Higashimoto Y, Appella E, Minucci S, Pandolfi PP, et al. 2000. PML regulates p53 acetylation and premature senescence induced by oncogenic Ras. Nature 406: 207-210.

Petitjean A, Mathe E, Kato S, Ishioka C, Tavtigian SV, Hainaut P, Olivier M. 2007. Impact of mutant p53 functional properties on TP53 mutation patterns and tumor phenotype: Lessons from recent developments in the IARC TP53 database. Hum Mutat 28: 622-629.
Razani B, Engelman JA, Wang XB, Schubert W, Zhang XL, Marks CB, Macaluso F, Russell RG, Li M, Pestell RG, et al. 2001. Caveolin-1 null mice are viable but show evidence of hyperproliferative and vascular abnormalities. J Biol Chem 276: 38121-38138.

Rego EM, Wang ZG, Peruzzi D, He LZ, Cordon-Cardo C, Pandolfi PP. 2001. Role of promyelocytic leukemia (PML) protein in tumor suppression. J Exp Med 193: 521-529.

Ribeiro RC, Sandrini F, Figueiredo B, Zambetti GP, Michalkiewicz E, Lafferty AR, DeLacerda L, Rabin M, Cadwell C, Sampaio G, et al. 2001. An inherited p53 mutation that contributes in a tissue-specific manner to pediatric adrenal cortical carcinoma. Proc Natl Acad Sci 98: 9330-9335.

Riley T, Sontag E, Chen P, Levine A. 2008. Transcriptional control of human p53-regulated genes. Nat Rev Mol Cell Biol 9: 402-412.

Rouault JP, Falette N, Guehenneux F, Guillot C, Rimokh R, Wang Q, Berthet C, Moyret-Lalle C, Savatier P, Pain B, et al. 1996. Identification of BTG2, an antiproliferative p53-dependent component of the DNA damage cellular response pathway. Nat Genet 14: 482-486.

Sablina AA, Budanov AV, Ilyinskaya GV, Agapova LS, Kravchenko JE, Chumakov PM. 2005. The antioxidant function of the p53 tumor suppressor. Nat Med 11: 13061313.

Schmitt CA, McCurrach ME, de Stanchina E, Wallace-Brodeur RR, Lowe SW. 1999. INK4a/ARF mutations accelerate lymphomagenesis and promote chemoresistance by disabling p53. Genes Dev 13: 2670-2677.

Schwartzenberg-Bar-Yoseph F, Armoni M, Karnieli E. 2004. The tumor suppressor p53 down-regulates glucose transporters GLUT1 and GLUT4 gene expression. Cancer Res 64: $2627-2633$.

Sengupta S, Harris CC. 2005. p53: Traffic cop at the crossroads of DNA repair and recombination. Nat Rev Mol Cell Biol 6: 44-55.

Shay JW, Roninson IB. 2004. Hallmarks of senescence in carcinogenesis and cancer therapy. Oncogene 23: 29192933.

Shibue T, Takeda K, Oda E, Tanaka H, Murasawa H, Takaoka A, Morishita Y, Akira S, Taniguchi T, Tanaka N. 2003. Integral role of Noxa in p53-mediated apoptotic response. Gene Dev 17: 2233-2238.

Srivastava S, Zou ZQ, Pirollo K, Plattner W, Chang EH 1990. Germ-line transmission of a mutated p53 gene in a cancer-prone family with $\mathrm{Li}-\mathrm{Fraumeni}$ syndrome. $\mathrm{Na}$ ture 348: 747-749.

Strasser A, Harris AW, Bath ML, Cory S. 1990. Novel primitive lymphoid tumours induced in transgenic mice by cooperation between $m y c$ and bcl-2. Nature 348: 331333.

Strasser A, Jost PJ, Nagata S. 2009. The many roles of FAS receptor signaling in the immune system. Immunity 30: $180-192$.

Strasser A, Cory S, Adams JM. 2011. Deciphering the rules of programmed cell death to improve therapy of cancer and other diseases. EMBO J 30: 3667-3683.

Taylor WR, Stark GR. 2001. Regulation of the $\mathrm{G}_{2} / \mathrm{M}$ transition by p53. Oncogene 20: 1803-1815.

Tront JS, Huang Y, Fornace AJ Jr, Hoffman B, Liebermann DA. 2010. Gadd45a functions as a promoter or suppres- 
B.J. Aubrey et al.

sor of breast cancer dependent on the oncogenic stress. Cancer Res 70: 9671-9681.

Valente LJ, Gray DH, Michalak EM, Pinon-Hofbauer J, Egle A, Scott CL, Janic A, Strasser A. 2013. p53 efficiently suppresses tumor development in the complete absence of its cell-cycle inhibitory and proapoptotic effectors p21, Puma, and Noxa. Cell Rep 3: 1339-1345.

Vassilev LT. 2005. p53 activation by small molecules: Application in oncology. J Med Chem 48: 4491-4499.

Vaux DL, Cory S, Adams JM. 1988. Bcl-2 gene promotes haemopoietic cell survival and cooperates with c-myc to immortalize pre-B cells. Nature 335: 440-442.

Ventura A, Kirsch DG, McLaughlin ME, Tuveson DA, Grimm J, Lintault L, Newman J, Reczek EE, Weissleder R, Jacks T. 2007. Restoration of p53 function leads to tumour regression in vivo. Nature 445: 661-665.

Villunger A, Michalak EM, Coultas L, Mullauer F, Bock G, Ausserlechner MJ, Adams JM, Strasser A. 2003. p53- and drug-induced apoptotic responses mediated by $\mathrm{BH} 3$ only proteins puma and noxa. Science 302: 1036-1038.

Vogelstein B, Lane D, Levine AJ. 2000. Surfing the p53 network. Nature 408: 307-310.

Vousden KH, Lane DP. 2007. p53 in health and disease. Nat Rev Mol Cell Biol 8: 275-283.
Wang PY, Ma W, Park JY, Celi FS, Arena R, Choi JW, Ali QA Tripodi DJ, Zhuang J, Lago CU, et al. 2013. Increased oxidative metabolism in the $\mathrm{Li}$-Fraumeni syndrome. $\mathrm{N}$ Engl J Med 368: 1027-1032.

Warburg O. 1956. On the origin of cancer cells. Science 123: 309-314.

Ward PS, Thompson CB. 2012. Metabolic reprogramming: A cancer hallmark even Warburg did not anticipate. Cancer Cell 21: 297-308.

Xue W, Zender L, Miething C, Dickins RA, Hernando E, Krizhanovsky V, Cordon-Cardo C, Lowe SW. 2007. Senescence and tumour clearance is triggered by $\mathrm{p} 53$ restoration in murine liver carcinomas. Nature 445: 656-660.

Yonish-Rouach E, Resnitzky D, Lotem J, Sachs L, Kimchi A, Oren M. 1991. Wild-type p53 induces apoptosis of myeloid leukaemic cells that is inhibited by interleukin-6. Nature 352: 345-347.

Youle RJ, Strasser A. 2008. The BCL-2 protein family: Opposing activities that mediate cell death. Nat Rev Mol Cell Biol 9: 47-59.

Younger ST, Kenzelmann-Broz D, Jung H, Attardi LD, Rinn JL. 2015. Integrative genomic analysis reveals widespread enhancer regulation by $\mathrm{p} 53$ in response to DNA damage. Nucleic Acids Res 43: 4447-4462. 


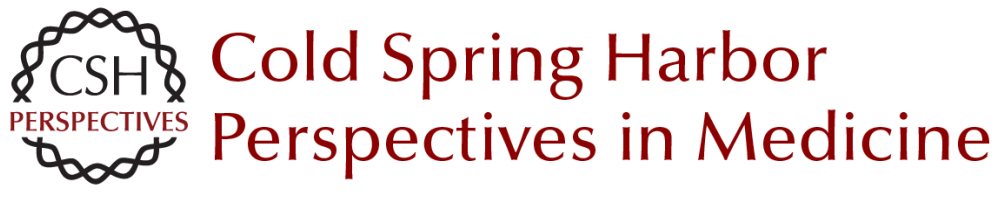

\section{Tumor-Suppressor Functions of the TP53 Pathway}

Brandon J. Aubrey, Andreas Strasser and Gemma L. Kelly

Cold Spring Harb Perspect Med 2016; doi: 10.1101/cshperspect.a026062

Subject Collection The p53 Protein

\section{Targeting the MDM2-p53 Protein-Protein Interaction for New Cancer Therapy: Progress and Challenges \\ Shaomeng Wang, Yujun Zhao, Angelo Aguilar, et al.}

Structural Evolution and Dynamics of the p53

Proteins

Giovanni Chillemi, Sebastian Kehrloesser,

Francesca Bernassola, et al.

Exploiting the p53 Pathway for Therapy Chit Fang Cheok and David Philip Lane

The Regulation of Cellular Functions by the p53

Protein: Cellular Senescence

Crystal A. Tonnessen-Murray, Guillermina Lozano and James G. Jackson

The Transactivation Domains of the p53 Protein Nitin Raj and Laura D. Attardi

The Evolution of the Ribosomal Protein-MDM2p53 Pathway

Chad Deisenroth, Derek A. Franklin and Yanping Zhang

Somatic TP53 Mutations in the Era of Genome

Sequencing

Pierre Hainaut and Gerd P. Pfeifer

The Paradox of p53: What, How, and Why?

Yael Aylon and Moshe Oren
Control of Cellular Aging, Tissue Function, and Cancer by p53 Downstream of Telomeres Caitlin M. Roake and Steven E. Artandi

Inherited TP53 Mutations and the Li -Fraumeni Syndrome

Tanya Guha and David Malkin

TP53 Mutations in Hypodiploid Acute Lymphoblastic Leukemia

Evan Q. Comeaux and Charles G. Mullighan

Transcriptional Regulation by Wild-Type and

Cancer-Related Mutant Forms of p53

Neil T. Pfister and Carol Prives

The Inherited p53 Mutation in the Brazilian

Population

Maria Isabel Achatz and Gerard P. Zambetti

TP53 Mutations in Breast and Ovarian Cancer Laxmi Silwal-Pandit, Anita Langerød and Anne-Lise Børresen-Dale

p53 and the Carcinogenicity of Chronic Inflammation

Andrei V. Gudkov and Elena A. Komarova

Oncogenic Mutant p53 Gain of Function

Nourishes the Vicious Cycle of Tumor

Development and Cancer Stem-Cell Formation

Yoav Shetzer, Alina Molchadsky and Varda Rotter

For additional articles in this collection, see http://perspectivesinmedicine.cshlp.org/cgi/collection/ 